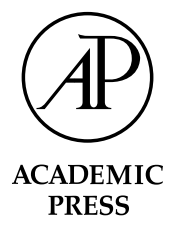

Available online at www.sciencedirect.com

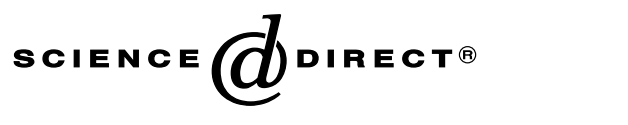

Archives of Biochemistry and Biophysics 409 (2003) 172-179

\title{
$\mathrm{ABB}$
}

www.elsevier.com/locate/yabbi

\section{Evaluation of thyroid hormone effects on liver P450 reductase translation}

\author{
Ekaterina V. Apletalina, Huan-Chen Li, and David J. Waxman* \\ Department of Biology, Boston University, 5 Cummington Street, Boston, MA 02215, USA
}

Received 30 May 2002, and in revised form 19 July 2002

\begin{abstract}
The expression of NADPH cytochrome P450 oxidoreductase (P450R) in rat liver is positively regulated by thyroid hormone (T3), at both the transcriptional and post-transcriptional levels. Here we investigate the effects of T3-induced hyperthyroidism on the regulation of P450R protein synthesis. T3 treatment of adult male rats led to a strong induction (up to $\sim 10$-fold) of liver P450R mRNA but little or no change in P450R protein and activity. Investigation of this discrepancy revealed that the association of hepatic P450R mRNA with polysomes was not altered by T3 treatment, suggesting that the discoordinate changes in P450R mRNA and protein levels do not reflect decreased recruitment of T3-induced P450R mRNA into polysomes. Moreover, polysome size distribution analysis of P450R mRNA did not show any T3-dependent changes. When assayed in an in vitro translation system, T3induced and uninduced P450R mRNAs were translated with similar efficiencies. Moreover, liver cell extract from T3-treated rats did not selectively inhibit in vitro translation of T3-induced P450R mRNA. Thus, neither structural changes in P450R mRNA nor transacting binding proteins in liver cytosol were found to control translation of P450R mRNA in response to T3 treatment. Taken together, these data suggest that P450R may in part be regulated at the level of protein stability in hyperthyroid rat liver.
\end{abstract}

(C) 2002 Elsevier Science (USA). All rights reserved.

Keywords: Cytochrome P450 reductase; Thyroid hormone; Gene expression; Post-transcriptional regulation

NADPH cytochrome P450 oxidoreductase (P450R) ${ }^{1}$ is a ubiquitous flavoprotein that transfers electrons from NADPH to several microsomal enzymes [1,2]. P450R is best known for its role in transferring electrons to cytochrome P450 (P450), which catalyzes metabolism of a wide range of lipophilic chemicals, including many drugs, environmental carcinogens and endogenous steroids, fatty acids, and alkaloids [3-5]. P450R also provides electrons to microsomal heme oxygenase, which oxidatively cleaves heme and plays an important role in cellular heme homeostasis [6]. In addition to its involvement in P450- and heme oxygenase-dependent

\footnotetext{
${ }^{*}$ Corresponding author. Fax: 1-617-353-7404.

E-mail address:djw@bu.edu .

${ }^{1}$ Abbreviations used: P450R, NADPH-dependent cytochrome P450 oxidoreductase; P450, cytochrome P450; T3, 3,3',5-triiodo-L-thyronine, thyroid hormone; ON, oligonucleotide; PCR, polymerase chain reaction; SDS-PAGE, sodium dodecyl sulfate-polyacrylamide gel electrophoresis; GST, glutathione-S-transferase; $5^{\prime}$ - or $3^{\prime}$-UTR, $5^{\prime}$ - or 3'-untranslated region.
}

metabolic processes, $\mathrm{P} 450 \mathrm{R}$ catalyzes reductive activation of quinones, including several anticancer quinone agents [7-9].

$\mathrm{P} 450 \mathrm{R}$ is encoded by a single gene consisting of 16 exons [10]. P450R is most highly expressed in liver, where it is subject to regulation by xenobiotics and by endogenous hormones, including thyroid hormone (T3) [1,11-14]. T3 regulates the expression of a variety of proteins in mammalian tissues at different levels. Similarly to malic enzyme [15], apolipoprotein E [16], $\mathrm{Na}, \mathrm{K}$ ATPase alpha 3 subunit [17], and osteocalcin [18], $\mathrm{P} 450 \mathrm{R}$ is regulated by $\mathrm{T} 3$ at both the transcriptional and post-transcriptional levels [12-14]. The transcriptional activation of $\mathrm{P} 450 \mathrm{R}$ by $\mathrm{T} 3$ is mediated by a thyroid response element in the $\mathrm{P} 450 \mathrm{R}$ promoter comprised of three imperfect direct repeats of the thyroid response motif AGGTCA [12]. T3 stimulates an increase in liver $\mathrm{P} 450 \mathrm{R}$ transcription, resulting in the induction of liver nuclear P450R precursor RNA within $12 \mathrm{~h}$ of hormone treatment [13]. The subsequent increase (up to $\sim 10$-fold) in cytoplasmic P450R mRNA [11] does not, however, 
lead to increases in hepatic P450R protein or activity, a finding that strongly suggests post-transcriptional regulation. T3 also induces a transient increase in P450R mRNA nuclear polyadenylation as well as destabilization of cytoplasmic P450R mRNA [14]; however, the consequences of these post-transcriptional effects of T3 are unknown.

The present study was undertaken to investigate the post-transcriptional events that may underlie the discoordinate changes in P450R mRNA and P450R protein and activity seen in hyperthyroid rat liver. We demonstrate that T3 does not alter the polyribosomal distribution of P450R mRNA. Moreover, using an in vitro translation system, we show that there is no change in the translational efficiency of P450R mRNA, either in the presence or in the absence of T3-induced liver cell extract. These findings are discussed in the context of several potential mechanisms whereby liver P450R may be regulated by changes in thyroid hormone status.

\section{Materials and methods}

Animals. Adult male Fischer 344 rats, housed under standardized conditions of light and temperature, were rendered hyperthyroid by a single i.p. injection of $\mathrm{T} 3$ (Sigma) at a receptor-saturating dose of $200 \mu \mathrm{g} / 100 \mathrm{~g}$ body weight. Control animals received the same volume $(0.3-0.5 \mathrm{ml})$ of vehicle $(0.01 \mathrm{M} \mathrm{KP}, \mathrm{pH} \sim 9.5$, containing $0.9 \% \mathrm{NaCl}$ ). Rats were killed $12-36 \mathrm{~h}$ later and individual livers stored frozen at $-80^{\circ} \mathrm{C}$. Animal experiments included two or three animals per time point. Where specified, total liver RNA and liver mRNA were purified from livers of untreated and T3-treated hypothyroid rats. Induction of hypothyroidism using the antithyroid drug methimazole $(0.025 \%(\mathrm{w} / \mathrm{v})$ in the drinking water for 16 days) followed by $\mathrm{T} 3$ injection ( $200 \mu \mathrm{g} / 100 \mathrm{~g}$ body weight) was described earlier [11].

$R N A$ isolation. Total RNA was purified from frozen liver samples using TRIzol reagent (Invitrogen) according to the manufacturer's instructions. mRNA was purified from total RNA using Oligotex mRNA midi kit (Qiagen).

Reverse transcription and real-time PCR. Total liver RNA $(0.4 \mu \mathrm{g})$ was reverse transcribed by murine leukemia virus reverse transcriptase (Applied Biosystems, Foster City, CA) or OmniScript reverse transcriptase (Qiagen) in a total reaction volume of $20 \mu 1$ using random hexamers, as recommended by the manufacturer. In some cases, total RNA was treated with 1 unit of RQ1 RNase-free DNase (Promega, Madison, WI) for $60 \mathrm{~min}$ at $37^{\circ} \mathrm{C}$ followed by heating for $5 \mathrm{~min}$ at $75^{\circ} \mathrm{C}$ prior to reverse transcription. Real-time PCR SYBR Green I assays were performed in triplicate for each sample using an ABI Prism 7900HT sequence detection system (Applied Biosystems). Primers were designed using Primer Express Software (Applied Biosystems) as follows: for P450R, forward primer 5'-CATGTCCG CAGACCCTGAA- ${ }^{\prime}$, reverse primer $5^{\prime}$-CGTATGTG GCCATGCAGAAG- $3^{\prime}$ (the corresponding amplicon spans 710 nucleotides of P450R intron 4 [10], thus making amplification of the P450R gene in contaminating genomic DNA less likely under the conditions of real-time PCR); for 18S rRNA, forward primer $5^{\prime}$ CGCCGCTAGAGGTGAAATTC- ${ }^{\prime}$, reverse primer 5'-CCAGTCGGCATCGTTTATGG-3'. The reaction mixture for the real-time PCR assay (total volume 4-10 $\mu$ l) contained SYBR Green I PCR master mix (Applied Biosystems), $300 \mathrm{nM}$ of each primer, and 200$1000 \mathrm{pg}$ (for P450R assay) or 1.7-10 pg (for 18S rRNA assay) of reverse transcribed liver cDNA. Relative quantitation of P450R RNA with normalization to $18 \mathrm{~S}$ rRNA was performed using the standard curve method, as described in the manufacturer's User Bulletin 2 (Applied Biosystems). Dissociation curves were generated after each real-time PCR run to ensure that a single specific product was amplified during the run.

In vitro translation. In vitro translation of total RNA or mRNA prepared from individual liver samples was carried out using reticulocyte lysate (Ambion, Austin, TX, or Promega). Reaction mixtures ( $25 \mu 1$ total volume) contained commercially supplied buffer, 9-20 $\mu \mathrm{g}$ total RNA or $0.8 \mu \mathrm{g}$ mRNA, $20 \mathrm{U}$ RNasin (Promega), $16.7 \mu$ reticulocyte lysate, and $2.1 \mu \mathrm{l}$ of $\left[{ }^{35} \mathrm{~S}\right]$ methionine (Perkin Elmer Life Sciences, Boston, MA). In some experiments, $8-70 \mu \mathrm{g}$ of liver cell extract from untreated or T3-treated hypothyroid rats was added to the reaction mixtures (for preparation of liver extracts, see below). The translation reaction was carried out at $30^{\circ} \mathrm{C}$ for 60-90 min and stopped by placing the tubes on ice. Duplicate aliquots ( $2 \mu \mathrm{l}$ each) were removed from each mixture to assess the overall level of radiolabel incorporation by precipitation of the proteins with $12.5 \%$ trichloroacetic acid (w/v). Precipitates were collected on glass fiber filters and counted in a liquid scintillation counter. The remaining portion of each translation mixture $(21 \mu \mathrm{l})$ was sequentially immunoprecipitated, first with anti-P450R antibody and then with anti-GST antibody. Immunoprecipitation was performed in $100 \mathrm{mM}$ sodium phosphate buffer, $\mathrm{pH}$ 7.4, containing $0.9 \% \mathrm{NaCl}, 1 \mathrm{mM}$ EDTA, $0.1 \%$ Triton $\mathrm{X}$ $100,0.5 \%$ Nonidet P-40, $1 \mathrm{mg} / \mathrm{ml}$ BSA, and Complete protease inhibitor cocktail (Roche Diagnostics GmbH, Mannheim, Germany) in a total volume of $400-500 \mu$ l. Translation reactions were incubated overnight with rabbit polyclonal P450R antibody (final dilution 1:400) [19], followed by removal of the anti-P450R-antigen complex using protein A-Sepharose CL-4B (Amersham Pharmacia Biotech, Uppsala, Sweden). The supernatants were subsequently incubated for $5 \mathrm{~h}$ with a rabbit polyclonal anti-GST $\alpha$ antibody (final dilution 1:500). Immunoprecipitated proteins were separated on $8.8 \%$ 
SDS-PAGE gels, which were analyzed with a Storm PhosphorImager and ImageQuant software (Molecular Dynamics, Sunnyvale, CA).

Preparation of liver extracts. A cytosolic extract was prepared from frozen livers using a modification of a method previously described [20]. All steps were performed at $4{ }^{\circ} \mathrm{C}$. Liver tissue $(\sim 1 \mathrm{~g})$ pooled from two untreated hypothyroid rats or from two T3-treated hypothyroid rats killed $12 \mathrm{~h}$ after T3 treatment was homogenized in $5 \mathrm{ml}$ of homogenization buffer $(10 \mathrm{mM}$ Tris- $\mathrm{HCl}, \mathrm{pH} 7.6,1 \mathrm{mM}$ EDTA, $250 \mathrm{mM}$ sucrose) containing $2 \times$ Complete protease inhibitor mixture (Roche Diagnostics $\mathrm{GmbH}$ ), $10 \mathrm{mM} \mathrm{NaF}$, and $1 \mathrm{mM}$ $\mathrm{Na}_{3} \mathrm{VO}_{4}$. Homogenates were centrifuged at $9000 \mathrm{rpm}$ for $20 \mathrm{~min}$ in a Sorvall SA-600 rotor, followed by centrifugation of the post-nuclear supernatant for $1 \mathrm{~h}$ at $45,000 \mathrm{rpm}$ in a Sorvall T-1270 rotor. Proteins were precipitated by adding solid ammonium sulfate to $60 \%$ saturation, collected by centrifugation for $2 \mathrm{~min}$ at $14,000 \mathrm{rpm}$ in a microcentrifuge, dissolved in buffer A $(20 \mathrm{mM}$ Tris- $\mathrm{HCl}, \mathrm{pH} 7.4,20 \mathrm{mM} \mathrm{KCl}, 7 \mathrm{mM} \beta-$ mercaptoethanol, $0.1 \mathrm{mM}$ EDTA, and $10 \%$ glycerol), and dialyzed overnight against buffer A. After dialysis, the extracts were briefly centrifuged to remove any undissolved material, and aliquots were stored at $-80^{\circ} \mathrm{C}$.

Northern blotting. Northern blotting of total liver RNA samples $(30 \mu \mathrm{g} / \mathrm{lane})$ was performed using $1 \%$ agarose gels containing $1.2 \mathrm{M}$ formaldehyde as described earlier [14]. The gels were probed with the following oligonucleotide probes and hybridization conditions: 5'-gCGCGGTCCTGTAGGTCTCT-3' (probe ON-762, complementary to rat P450R mRNA untranslated exon 1, nt $1-19$; probe hybridized at $45^{\circ} \mathrm{C}$ in the presence of $15 \%$ formamide) and $5^{\prime}$-TAGCGGCCCTTGGTCATCAG-3' (probe ON-28, complementary to rat P450R mRNA exon 16, nt 1999-2019; probe hybridized at $50{ }^{\circ} \mathrm{C}$ in the presence of $10 \%$ formamide) [14]. Oligonucleotide probe ON-4 complementary to rat P450 2C6 mRNA and hybridization conditions were described previously [13].

Preparation of microsomes. Portions of individual frozen livers $(200-400 \mathrm{mg})$ were homogenized on ice in a mechanical homogenizer (8-9 strokes) with $2 \mathrm{ml}$ of $10 \mathrm{mM}$ Tris- $\mathrm{HCl}$ buffer, $\mathrm{pH}$ 7.6, containing $1 \mathrm{mM}$ EDTA, $250 \mathrm{mM}$ sucrose, $2 \times$ Complete protease inhibitor mixture (Roche Diagnostics $\mathrm{GmbH}$ ), $10 \mathrm{mM} \mathrm{NaF}$ and $1 \mathrm{mM} \mathrm{Na} \mathrm{NO}_{4}$. Samples were centrifuged for $20 \mathrm{~min}$ at $9000 \mathrm{rpm}$ at $4{ }^{\circ} \mathrm{C}$ in a Sorvall SA-600 rotor. The supernatants were then centrifuged for $1 \mathrm{~h}$ at 45,000 at $4{ }^{\circ} \mathrm{C}$ in a Sorvall T-1270 rotor. Microsome pellets were resuspended in $100 \mathrm{mM}$ potassium phosphate buffer, $\mathrm{pH} 7.4,0.1 \mathrm{mM}$ EDTA, and 20\% glycerol, aliquoted, and stored at $-80^{\circ} \mathrm{C}$.

Enzymatic activity and western blotting. Liver microsomal P450R activity was assayed by cytochrome c reduction [21]. Western blotting was performed using polyclonal rabbit antibody raised to rat liver P450R [19]. Primary antibody dilution was 1:3000.

Polysome preparation and fractionation. Liver polysome preparation and polysome fractionation were performed as described [22]. Briefly, rat livers were homogenated in RS buffer $(200 \mathrm{mM}$ Tris- $\mathrm{HCl}, \mathrm{pH} 8.5$, $50 \mathrm{mM} \mathrm{KCl}, 40 \mathrm{mM} \mathrm{MgCl} 2,25 \mathrm{mM}$ EGTA, $0.25 \mathrm{M}$ sucrose, $5 \mathrm{mM}$ dithiothreitol, $1 \mathrm{unit} / \mu \mathrm{l}$ RNasin (Promega) and $2 \mu \mathrm{g} / \mathrm{ml}$ cycloheximide). Triton $\mathrm{X}-100$ was added to the homogenates to a final concentration of $2.5 \%$, and the mixtures were centrifuged for $16 \mathrm{~min}$ at $12,000 \mathrm{~g}$. The supernatants were applied on a discontinuous sucrose gradient consisting of an upper cushion of $1.0 \mathrm{M}$ sucrose and a lower cushion of $1.9 \mathrm{M}$ sucrose, both in RS buffer containing $0.25 \mathrm{U} / \mu \mathrm{l} \mathrm{RNasin}$. The samples were centrifuged for $2.5 \mathrm{~h}$ at $250,000 \mathrm{~g}$ at $4{ }^{\circ} \mathrm{C}$. Polysomal pellets were resuspended in $1.25 \mathrm{ml} \mathrm{RS}$ buffer and stored frozen. To size-fractionate the polysomes, the polysomal pellets $(0.25 \mathrm{ml})$ were loaded onto $10 \mathrm{ml}, 15-57 \%$ linear sucrose gradients. Samples were centrifuged for $105 \mathrm{~min}$ at $250,000 \mathrm{~g}$ at $4{ }^{\circ} \mathrm{C}$. Twelve fractions were collected using a 1-ml pipet, with the polysome peak $\left(\mathrm{A}_{260}\right)$ typically localized to fractions 7-8. Total RNA was prepared from polysomes and polysomal fractions using TRIzol reagent (Invitrogen) and analyzed by Northern blotting as described above.

\section{Results}

We first investigated the effects of $\mathrm{T} 3$ treatment on liver P450R mRNA, protein, and activity. Euthyroid rats were given a single, receptor-saturating dose of $\mathrm{T} 3$ and then killed at times ranging from 12 to $36 \mathrm{~h}$ later. Total liver RNA was isolated and P450R mRNA levels assayed by two methods: Northern blotting with an antisense oligonucleotide probe complementary to P450R untranslated exon 1; and real-time PCR amplification of a 100-bp P450R cDNA fragment spanning the junction between P450R exon 4 and exon 5 (Fig. 1A). Microsomes prepared from the same livers were assayed for P450R protein and P450R activity (Fig. 1B). Induction of P450R mRNA was readily detected at all time points tested $(12,16,24$, and $36 \mathrm{~h})$. Real-time PCR analysis showed that P450R mRNA was increased $\sim 3-$ fold $24 \mathrm{~h}$ after $\mathrm{T} 3$ injection (panel A, bottom right). Northern blot analysis gave a slightly different induction pattern (panel A, top, and bottom left); depending on the background correction method, the induction value varied from $\sim 2.5$ - to 4 -fold.

In contrast to P450R mRNA, microsomal P450R protein and activity levels were only slightly altered by T3 treatment (Fig. 1, panel B). P450R protein increased $\sim 30 \%$ by $16 \mathrm{~h}$, while P450R activity (cytochrome c reduction) was virtually unchanged over the 36 -h time course. In a separate experiment, where euthyroid rats 

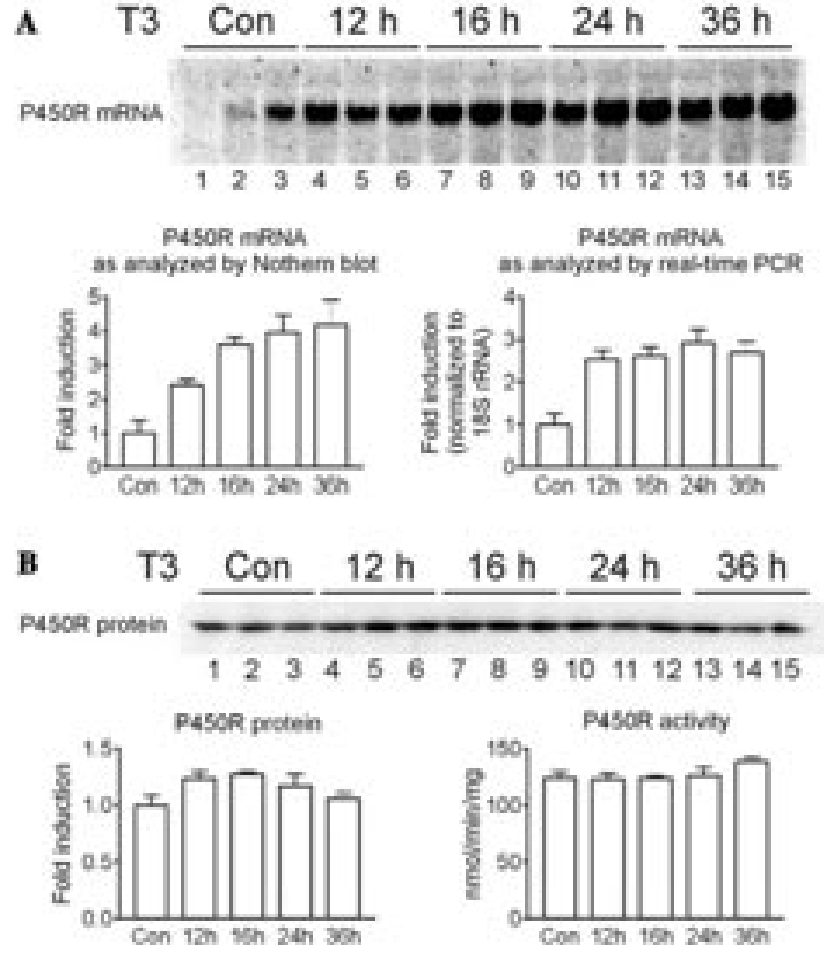

Fig. 1. Effect of T3 treatment on P450R mRNA, protein and activity in rat liver. Euthyroid male rats were given a single i.p. injection of T3 and were killed $12,16,24$, or $36 \mathrm{~h}$ later (three rats per time point). Control rats (three animals) received a vehicle injection and were killed $12 \mathrm{~h}$ later. Total RNA and microsomes were isolated from individual livers. Panel A. T3 induction of P450R mRNA. Top: Northern blot analysis of total RNA samples $(30 \mu \mathrm{g})$ resolved on a $1 \%$ agarose/1.2 M formaldehyde gel and probed with a single-stranded oligonucleotide complementary to P450R mRNA exon 1 (ON-762). The large variation in P450R mRNA in control livers seen in this experiment (lanes 13 ) is not typical. In other experiments, the variation in P450R mRNA in control livers was considerably smaller. Bottom left: Phosphorimager quantitation of P450R mRNA Northern blot bands. Bottom right: Quantitation of P450R mRNA by real-time PCR. Shown is the fold-induction of P450R mRNA following T3 treatment after normalization to $18 \mathrm{~S}$ rRNA. Real-time PCR assays of P450R mRNA and $18 \mathrm{~S}$ rRNA were performed following reverse transcription of total RNA samples from individual livers. The difference in fold-induction of P450R mRNA obtained by Northern blot analysis and by real-time PCR may be partially attributed to the difficulty of quantitating the low intensities of Northern blot bands in control samples (lanes 1 and 2). Panel B. Effect of T3 on liver P450R protein and activity. Shown is a Western blot of $\mathrm{P} 450 \mathrm{R}$ in liver microsomes $(45 \mu \mathrm{g})$ (top) with quantitation of the band intensities (bottom, left). P450R activity (cytochrome c reduction rates) was assayed in isolated liver microsomes as described in Materials and methods (bottom, right). Data shown here are mean values $\pm \operatorname{SEM}(n=3)$.

were killed 12 and $24 \mathrm{~h}$ after T3 injection, T3 stimulated $\mathrm{a} \sim 2.7$-fold induction of P450R mRNA by $24 \mathrm{~h}$, whereas P450R protein and activity increased by only $\sim 40 \%$ and $30 \%$, respectively (data not shown). These data support the conclusion that the induction of P450R mRNA by $\mathrm{T} 3$ is not accompanied by a correspondingly large increase in $\mathrm{P} 450 \mathrm{R}$ protein and activity.
T3 does not alter the association of P450R $m R N A$ with polysomes

To investigate whether translational regulation could potentially explain the discoordinate changes in P450R mRNA and protein levels seen in hyperthyroid rats, we tested whether T3-induced P450R mRNA is poorly associated with polysomes, which would result in low efficiency of P450R protein synthesis. To determine if such a mechanism is operative, we isolated polysomal fractions from livers of untreated and T3-treated rats. Triton X-100-treated liver homogenates were centrifuged through a discontinuous sucrose gradient, following which total liver RNA was purified from the polysomes and analyzed on Northern blots probed with an oligonucleotide complementary to P450R mRNA. As evident in Fig. 2 (panel A, top), the fold-induction by T3 of polysome-associated P450R mRNA was at least as great as that seen for the total liver RNA fraction. Reprobing for P450 2C6 mRNA, which is not responsive to T3 [23], served as a loading control (Fig. 2, panel A, bottom).
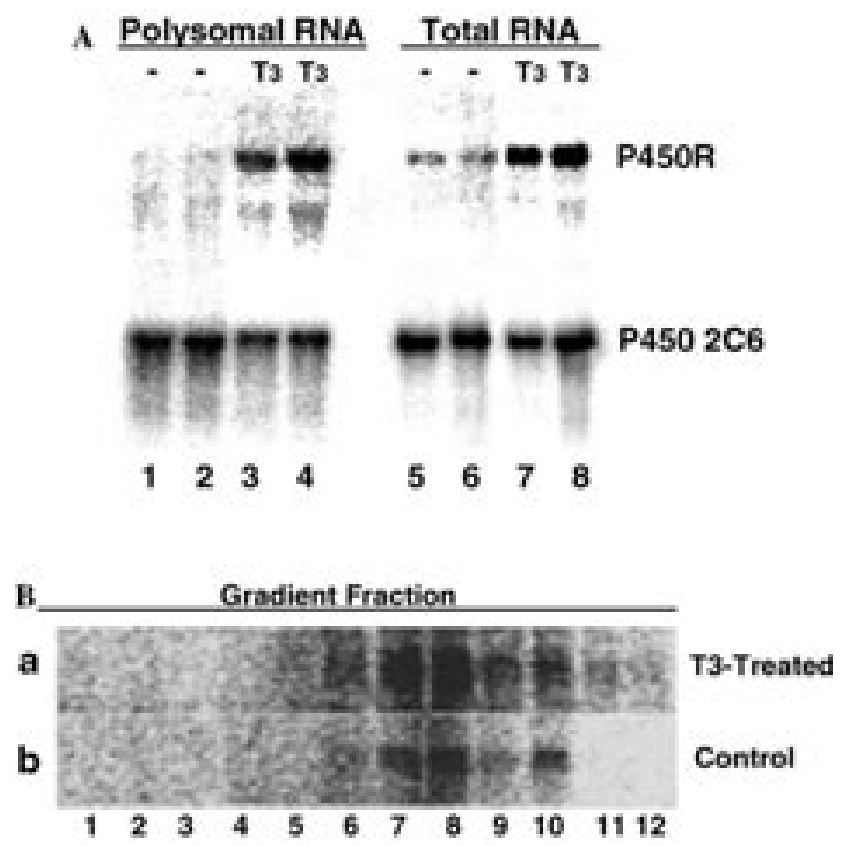

Fig. 2. Effect of $\mathrm{T} 3$ on association of P450R mRNA with polysomes. Panel A. T3 induction of polysome-associated P450R mRNA. Euthyroid male rats (two rats per group) were given a single i.p. injection of $\mathrm{T} 3$ or a vehicle and were killed $12 \mathrm{~h}$ later. Liver homogenates from these rats were treated with Triton X-100 to release polysomes from the endoplasmic reticulum membrane, and polysomes were prepared by passing through a discontinuous $1.0 \mathrm{M} / 1.9 \mathrm{M}$ sucrose gradient. Polysomal RNA and total RNA from control rats (lanes 1, 2, 5, 6) and T3-treated rats (lanes 3, 4, 7, 8) was analyzed by Northern blotting with oligonucleotide probes specific to P450R (ON-28) (top) or P450 2C6 mRNA (bottom). Panel B. Polysomal size distribution of P450R mRNA. Polysomes isolated from T3-treated (top) and control (bottom) rat liver were fractionated on a $15-57 \%$ linear sucrose gradient. Total RNA purified from the collected fractions was analyzed by Northern blotting with a P450R-specific oligonucleotide probe. 
This finding suggests that $\mathrm{T} 3$ treatment does not lead to inefficient association of P450R mRNA with polysomes. Further support for this conclusion was obtained by analysis of $\mathrm{P} 450 \mathrm{R}$ polysome size distribution when fractionated on a linear sucrose gradient and analyzed by Northern blotting. As shown in Fig. 2, panel B, the polysomal size distribution of P450R mRNA was not altered by $\mathrm{T} 3$ treatment. We conclude that the absence of a large increase in $\mathrm{P} 450 \mathrm{R}$ protein in T3-treated rat liver does not reflect decreased recruitment of P450R mRNA into high molecular weight polysomes.

\section{P450R $m R N A$ isolated from untreated and T3-treated rats has a similar in vitro translation efficiency}

T3-induced structural changes in P450R mRNA could potentially account for the discoordinate changes in P450R mRNA and P450R protein and activity seen in T3-treated rats. Indeed, T3 stimulates an increase in liver P450R poly(A) tail length $\sim 12 \mathrm{~h}$ after hormone treatment [14]. To determine whether T3-induced P450R mRNA has an intrinsically poor translation efficiency due to this or other structural alterations, total liver RNA isolated from control rats and from 12 or $24 \mathrm{~h} \mathrm{T3-}$ treated euthyroid rats was translated in an in vitro translation system in the presence of $\left[{ }^{35} \mathrm{~S}\right]$ methionine. Translation reactions were sequentially immunoprecipitated with anti-P450R antibody and anti-GST antibody, followed by SDS-PAGE and phosphorimaging. Fig. 3, panel A, shows that the yield of P450R protein in an in vitro translation system increased when 12-h or 24$\mathrm{h}$ T3-induced total liver RNA was used as a template as compared to uninduced total liver RNA (lanes 3-6 vs lanes 1 and 2). When the intensities of the ${ }^{35} \mathrm{~S}$-labeled P450R bands (lanes 1-6) were normalized to the intensities of the GST bands (lanes 7-12), the yield of P450R obtained with 12-h and 24-h T3-induced RNA was, respectively, 2.2 and 2.7 times higher than that obtained with control RNA. These values are similar to the foldinduction of P450R mRNA seen in the same RNA samples (data not shown). Thus, P450R mRNA isolated from all three groups of rats (untreated euthyroid rats, and euthyroid rats killed 12 and $24 \mathrm{~h}$ after T3 treatment) is translated with a similar efficiency in vitro.

To confirm our finding that $\mathrm{T} 3$ treatment does not affect the translation efficiency of P450R mRNA, we repeated the in vitro translation experiments using liver mRNA from untreated and T3-treated hypothyroid rats. Methimazole-induced hypothyroid rats show a response similar to that seen in euthyroid rats: a single injection of $\mathrm{T} 3$ at a receptor-saturating dose substantially increases P450R mRNA with little change in $\mathrm{P} 450 \mathrm{R}$ protein and activity [11]. T3 induction of liver P450R mRNA in the hypothyroid rats used for these in vitro experiments was significantly higher ( 18 -fold) than in the euthyroid rats ( $\sim 3$-fold $)$ examined in Fig. 3,
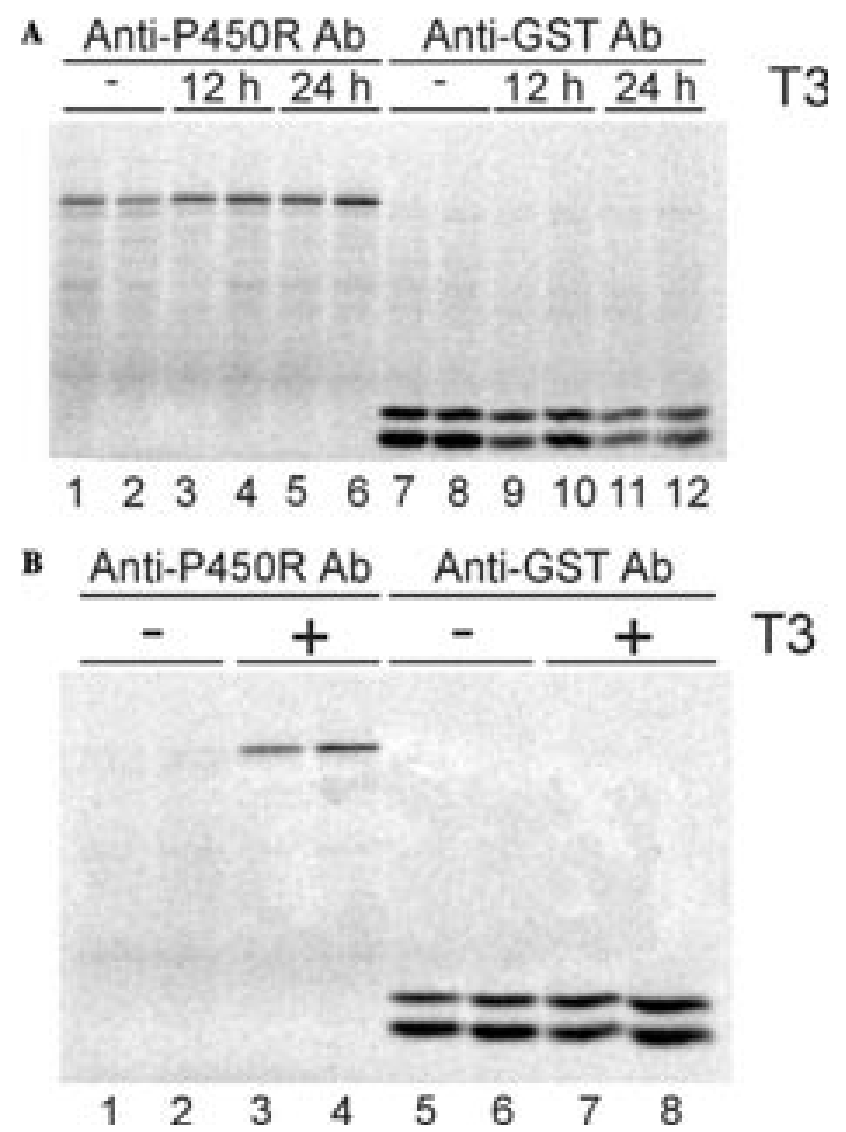

Fig. 3. T3-induced P450R mRNA is translated in vitro with efficiency comparable to that of uninduced P450R mRNA. Panel A. In vitro translation of total liver RNA from T3-treated and untreated euthyroid rats. Euthyroid rats (two rats per group) received a single i.p. injection of $\mathrm{T} 3$ or a vehicle and were killed 12 or $24 \mathrm{~h}$ later, as marked. Equal quantities of total RNA $(9 \mu \mathrm{g})$ were translated in a reticulocyte in vitro translation system in the presence of $\left[{ }^{35} \mathrm{~S}\right]$ methionine, followed by sequential immunoprecipitation with anti-P450R (lanes 1-6) and anti-GST antiserum (lanes 7-12). The samples were analyzed by SDSPAGE followed by the phosphoimager analysis. Panel B. In vitro translation of mRNA from T3-treated and untreated hypothyroid rats. Hypothyroid male rats (two animals per group) received a single i.p. injection of $\mathrm{T} 3$ or a vehicle (as marked) and were killed $12 \mathrm{~h}$ later. mRNA $(0.8 \mu \mathrm{g})$ purified from individual livers was translated in a reticulocyte in vitro translation system. The other conditions were the same as in panel A.

panel A (data not shown), making it easier to evaluate the impact of T3 treatment on the efficiency of P450R mRNA translation in vitro. In vitro translation of liver mRNA from untreated and $12 \mathrm{~h} \mathrm{T3-treated} \mathrm{hypothyroid}$ rats resulted in a substantially higher yield of ${ }^{35} \mathrm{~S}$-labeled P450R protein in the case of the T3-induced mRNA (Fig. 3, panel B; lanes 3, 4 vs lanes 1,2; cf. GST controls in lanes 5-8), in agreement with the much higher P450R mRNA content of the T3-treated liver samples. We conclude that $\mathrm{T} 3$ treatment does not affect the in vitro translation efficiency of P450R mRNA, suggesting that the poor responsiveness of $\mathrm{P} 450 \mathrm{R}$ protein to $\mathrm{T} 3$ is not due to structural changes in P450R mRNA. 


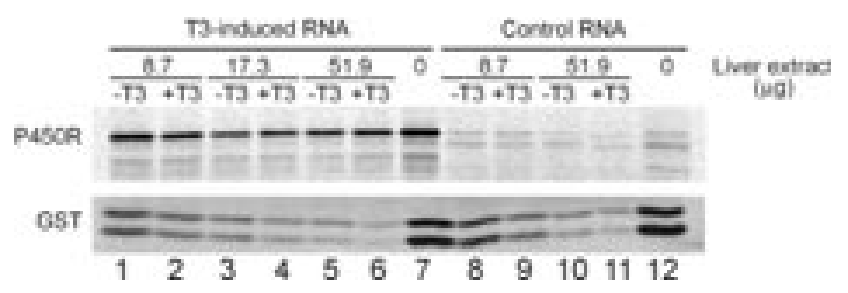

Fig. 4. Effect of liver cytoplasmic extracts from T3-treated and untreated rats on in vitro translation of P450R. Cytoplasmic extracts and total RNA were prepared from livers of hypothyroid rats that were given a single i.p. injection of T3 or a vehicle and were killed $12 \mathrm{~h}$ later. Different amounts of the cytoplasmic protein extract (as marked) were added to a reticulocyte in vitro translation reaction containing $\left[{ }^{35} \mathrm{~S}\right]$ methionine and total RNA isolated from either a T3-treated or an untreated rat (15 and $20 \mu \mathrm{g}$, respectively). The translation products were immunoprecipitated sequentially with anti-P450R (top panel) and anti-GST antiserum (bottom panel) and analyzed by SDS-PAGE followed by phosphoimager analysis.

Liver cytosolic proteins do not alter the translation of P450R $\mathrm{mRNA}$ in response to T3 treatment

Another possible mechanism for translational regulation of P450R could involve induction by $\mathrm{T} 3$ of a soluble trans-acting protein that binds to P450R mRNA and inhibits its translation. To determine if such a transacting protein is induced by $\mathrm{T} 3$, we prepared extracts from livers of untreated and $12 \mathrm{~h}$ T3-treated hypothyroid rats. Total liver RNA was translated in vitro in the presence of $\left[{ }^{35} \mathrm{~S}\right]$ methionine and in the presence or absence of the soluble liver extract. Immunoprecipitation analysis was performed using anti-P450R antibody and anti-GST antibody, as described above, followed by SDS-PAGE and phosphorimaging. Liver cytosolic extracts from untreated and T3-treated hypothyroid rats exhibited a nonspecific inhibition of the translation reaction, as indicated by the decrease in the overall $\left[{ }^{35} \mathrm{~S}\right]$ methionine incorporation in the presence of either liver extract (up to $55 \%$ decrease in the presence of $52 \mu \mathrm{g}$ of liver cytosolic protein; data not shown). However, neither of the liver extracts exerted a specific inhibitory effect on the translation of P450R mRNA (Fig. 4). By contrast, T3-treated rat liver extract was somewhat more inhibitory to the translation of the GST mRNAs as compared to untreated rat liver extract (cf. lanes 2, 4, $6,9,11$ vs lanes $1,3,5,8,10)$. This observation is consistent with the report that GST is regulated by thyroid hormone at a post-transcriptional level [24]. Overall, we did not find any trans-acting factors in the liver extracts that affected the translation of $\mathrm{P} 450 \mathrm{R}$ mRNA in a T3-dependent manner.

\section{Discussion}

Normal thyroid hormone levels are required for maintenance of P450R mRNA, protein, and activity, as well as P450R-dependent P450 monooxygenase activity, in rat liver $[11,21]$. T3 has been shown to regulate P450R at the transcriptional level [13], and also post-transcriptionally, through effects on P450R mRNA stability and poly(A) tail length [14]. Further evidence for posttranscriptional effects of T3 on P450R is provided by the finding that $\mathrm{T} 3$ treatment of rats induces a substantial increase in liver P450R mRNA with little or no changes in P450R protein and activity levels. The present study extends our previous observations regarding this discoordinate regulation of $\mathrm{P} 450 \mathrm{R}$ protein/activity vs $\mathrm{P} 450 \mathrm{R}$ mRNA [11] and explores several possible mechanisms of translational regulation that could underlie this response.

Translation can be regulated by several mechanisms, including the association of mRNA with polysomes, which provides a general indication of the efficiency of translational initiation. A classic example of this type of control is the regulation of ferritin mRNA translation by iron, where the binding of iron regulatory protein to the $5^{\prime}$-untranslated region (5'-UTR) of ferritin mRNA results in the dissociation of ferritin mRNA from polysomes [25]. T3 can modulate this binding of the iron regulatory protein to ferritin mRNA [26]. To determine if $\mathrm{T} 3$ treatment of rats resulted in an inefficient association of P450R mRNA with polysomes, we analyzed polysomes prepared from control and T3-stimulated euthyroid rats. The fold-induction by $\mathrm{T} 3$ of polysomebound P450R mRNA was found to be similar to that seen when analyzing total liver P450R RNA. Moreover, no shift in the polysome size distribution of P450R mRNA was seen when comparing T3-treated vs untreated rat livers. These data indicate that $\mathrm{T} 3$ does not selectively inhibit polysome association of P450R mRNA and thus is not likely to inhibit P450R mRNA translation initiation by such a mechanism.

T3 treatment could conceivably render P450R mRNA poorly translatable due to a change in mRNA structure. To examine this possibility, total liver RNA and liver mRNA were translated in vitro in reticulocyte lysates. We found that P450R mRNAs from T3-treated and untreated rats were translated with similar efficiencies, indicating that the intrinsic translatability of P450R mRNA is not altered by T3. We previously found that T3 treatment of euthyroid rats leads to a transient increase in P450R mRNA poly(A) tail length, which is detectable in the cytoplasm $12 \mathrm{~h}$ after hormone treatment and is reversed by $16 \mathrm{~h}$ [14]. An increase in poly(A) tail length is often associated with an increase in mRNA translation [27,28]. In the present study, however, no difference was found in the efficiency of translation in vitro between P450R mRNA from control euthyroid rats vs. P450R mRNA from hyperthyroid rats, killed $12 \mathrm{~h}$ after T3 injection. These data suggest that the presence of a longer poly(A) tail does not in and of itself alter the translational efficiency of P450R mRNA. We 
cannot exclude the possibility, however, that certain cytosolic liver proteins, which were absent from the in vitro translation system used in these experiments, could affect the translation of P450R mRNA in a manner that depends on P450R's poly(A) tail length.

Translational regulation can also occur through interactions of trans-acting proteins with either the $5^{\prime}$ - or $3^{\prime}$-UTR of an mRNA. T3 regulation of lipoprotein lipase in rat adipocytes involves such a mechanism [29]. The trans-acting proteins described to date act as negative regulators of translation $[28,30]$. The inhibition of translation by protein-mRNA interactions does not necessary involve changes in the association of mRNA with polysomes. Examples include the regulation of lipoprotein lipase by epinephrine [20] and under conditions of diabetes [31]. To assay if trans-acting binding factors are involved in the inhibition of P450R mRNA translation in response to T3 treatment, we prepared liver extracts from untreated and T3-treated hypothyroid rats. Total RNA from untreated or T3-treated hypothyroid rats was translated in vitro in the presence of either liver extract. We found no specific inhibitory effect of cytosolic extract from T3-treated rats on P450R mRNA translation as compared to extract from untreated animals. These data suggest that trans-acting binding proteins are not involved in the regulation of liver P450R mRNA in response to T3.

Thus, we assessed several potential mechanisms of P450R translational control and did not find any of them to be involved in the regulation of P450R by T3. Taken together, our findings suggest that $\mathrm{P} 450 \mathrm{R}$ protein levels may be regulated by $\mathrm{T} 3$ post-translationally. The discoordinate changes in P450R mRNA vs protein and activity levels seen in T3-treated liver may reflect, at least in part, an increase in the rate of $\mathrm{P} 450 \mathrm{R}$ protein degradation. Thyroid control of gene expression at the level of protein degradation has been shown for type I collagen [32]. In cultured rat hepatic Ito cells, T3 treatment decreases type I collagen production by $\sim 3$-fold by decreasing the intracellular half-life of collagen [32]. Determination of the effects of $\mathrm{T} 3$ on the degradation of P450R protein in vitro or, preferably, on the half-life of P450R protein in liver in vivo or in primary hepatocyte cultures should help determine if the regulation of $\mathrm{P} 450 \mathrm{R}$ by $\mathrm{T} 3$ involves the control of $\mathrm{P} 450 \mathrm{R}$ protein degradation.

It is uncertain whether the overall pattern of P450R's response to T3, i.e., substantial induction of P450R mRNA with little change in $\mathrm{P} 450 \mathrm{R}$ protein, is limited to T3 treatment, or whether it occurs with other inducers of P450R as well. Treatment of rats with the classical cytochrome P450-inducing agents phenobarbital and dexamethasone results in a significant increase in cytoplasmic P450R mRNA, 10-fold for phenobarbital and 7-fold for dexamethasone within, respectively, $6 \mathrm{~h}$ and $9 \mathrm{~h}$ of inducer treatment [33,34]. Unfortunately, P450R protein and activity levels were not measured at the time points when the maximal increases in P450R mRNA were observed. However, the increase in $\mathrm{P} 450 \mathrm{R}$ protein and activity in phenobarbital-treated rat liver may be substantially lower than the increase in P450R mRNA, as suggested by our finding that daily phenobarbital treatment of rats for 4 days induces liver P450R mRNA 3.4-fold, whereas liver microsomal P450R activity increases by only $70 \%$ (E.V.A. and D.J.W, unpublished data). Thus, the discoordinate regulation of P450R mRNA and protein/activity seen in hyperthyroid rat liver may reflect a more general requirement for hepatocytes to maintain the level of P450R activity within a relatively narrow ( $\sim 2-3$-fold) range and to avoid strong $\mathrm{P} 450 \mathrm{R}$ overexpression, which may be associated with reactive oxygen toxicity. Further investigation is required to address this point and to fully elucidate the multiple responses of $\mathrm{P} 450 \mathrm{R}$ to changes in hormonal and environmental factors that regulate $\mathrm{P} 450 \mathrm{R}$ synthesis and degradation.

\section{Acknowledgments}

This article is dedicated to Dr. Ronald W. Estabrook in appreciation of his outstanding scientific leadership, as well as his mentorship and support for the past 20 years. Supported in part by National Institute of Health Grant DK53767 (to D.J.W.).

\section{References}

[1] A.L. Shen, C.B. Kasper, in: J.B. Schenkman, H. Greim (Eds.), Cytochrome P450, Springer, Berlin, 1993, pp. 35-59.

[2] H.W. Strobel, A.V. Hodgson, S. Shen, in: P.R. Ortiz de Montellano (Ed.), Cytochrome P450. Structure, Mechanism, and Biochemistry, Plenum, San Francisco, 1995, pp. 225-244.

[3] T.D. Porter, M.J. Coon, J. Biol. Chem. 266 (1991) 13469-13472.

[4] F.P. Guengerich, Chem. Biol. Interact. 106 (1997) 161-182.

[5] F.P. Guengerich, T. Shimada, Mutat. Res. 400 (1998) 201-213.

[6] M.D. Maines, Annu. Rev. Pharmacol. Toxicol. 37 (1997) 517-554.

[7] A.V. Patterson, M.P. Saunders, E.C. Chinje, D.C. Talbot, A.L. Harris, I.J. Strafford, Br. J. Cancer 76 (1997) 1338-1347.

[8] A.O. Sawamura, T. Aoyama, K. Tamakoshi, K. Mizuno, N. Suganuma, F. Kikkawa, Y. Tomoda, Oncology 53 (1996) 406-411.

[9] P.L. Chesis, D.E. Levin, M.T. Smith, L. Ernster, B.N. Ames, Proc. Natl. Acad. Sci. U.S.A. 81 (1984) 1696-1700.

[10] T.D. Porter, T.W. Beck, C.B. Kasper, Biochemistry 29 (1990) 9814-9818.

[11] P.A. Ram, D.J. Waxman, J. Biol. Chem. 267 (1992) 3294-3301.

[12] K.A. O'Leary, H.C. Li, P.A. Ram, P. McQuiddy, D.J. Waxman, C.B. Kasper, Mol. Pharmacol. 52 (1997) 46-53.

[13] H.C. Li, D. Liu, D.J. Waxman, Mol. Pharmacol. 59 (2001) 987-995.

[14] D. Liu, D.J. Waxman, Mol. Pharmacol. 61 (2002) 1089-1096.

[15] M.K. Song, B. Dozin, D. Grieco, J.E. Rall, V.M. Nikodem, J. Biol. Chem. 263 (1988) 17,970-17,974. 
[16] Y. Vandenbrouck, B. Janvier, C. Loriette, G. Bereziat, M. Mangeney-Andreani, Eur. J. Biochem. 224 (1994) 463-471.

[17] M. Bajpai, S. Chaudhury, Neuroreport 10 (1999) 2325-2328.

[18] C.H. Gouveia, J.J. Schultz, A.C. Bianco, G.A. Brent, J. Endocrinol. 170 (2001) 667-675.

[19] S.F. Ng, D.J. Waxman, Cancer Res. 50 (1990) 464-471.

[20] A. Yukht, R.C. Davis, J.M. Ong, G. Ranganathan, P.A. Kern, J. Clin. Invest. 96 (1995) 2438-2444.

[21] D.J. Waxman, J.J. Morrissey, G.A. Leblanc, Mol. Pharmacol. 35 (1989) 519-525.

[22] H.L. Foyt, D. LeRoith, C.T. Roberts Jr., J. Biol. Chem. 266 (1991) 7300-7305.

[23] P.A. Ram, D.J. Waxman, Mol. Endocrinol. 5 (1991) 13-20.

[24] S. Coecke, T. Vanhaecke, A. Foriers, I.R. Phillips, A. Vercruysse, E.A. Shephard, V. Rogiers, J. Endocrinol. 166 (2000) 363-371.

[25] J.B. Harford, R.D. Klausner, Enzyme 44 (1990) 28-41.
[26] P.J. Leedman, A.R. Stein, W.W. Chin, J.T. Rogers, J. Biol. Chem. 271 (1996) 12,017-12,023.

[27] R.J. Jackson, N. Standart, Cell 62 (1990) 15-24.

[28] N.K. Gray, M. Wickens, Annu. Rev. Cell. Dev. Biol. 14 (1998) 399-458.

[29] P.A. Kern, G. Ranganathan, A. Yukht, J.M. Ong, R.C. Davis, J. Lipid. Res. 37 (1996) 2332-2340.

[30] N. Standart, R.J. Jackson, Biochimie 76 (1994) 867-879.

[31] G. Ranganathan, C. Li, P.A. Kern, J. Biol. Chem. 275 (2000) 40986-40991.

[32] T.W. Lissoos, D.W. Beno, B.H. Davis, Am. J. Physiol. 264 (1993) G1090-1095.

[33] J.P. Hardwick, F.J. Gonzalez, C.B. Kasper, J. Biol. Chem. 258 (1983) 8081-8085.

[34] D.L. Simmons, P. McQuiddy, C.B. Kasper, J. Biol. Chem. 262 (1987) 326-332. 